From the Division of Avian Diseases, Indian Veterinary Research Institute, Izatnagar, India, and the Department of Pathology, Faculty of Veterinary Medicine, Swedish University of Agricultural Sciences, Uppsala, Sweden.

\title{
Electron Microscopy of Bursa of Fabricius of Chicks Infected with a Field Strain of Infectious Bursal Disease Virus
}

\author{
By A. S. Panisup, B. Järplid, K. C. Verma and G. C. Mohanty
}

\begin{abstract}
Panisup A. S., B. Järplid, K. C. Verma and G. C. Mohanty: Electron microscopy of bursa of Fabricius of chicks infected with a field strain of infectious bursal disease virus. Acta. vet. scand. 1988, 29, 125-127. Chicks were infected in the bursa with a field strain of infectious bursal disease virus. Inter- and intracellular edema, condensation and margination of nuclear chromatin, increased number of lysosomes in macrophages, and lymphocytolytic changes appeared earliest by 8 hours post infection. Inclusions containing spheroid to hexagonal virus particles were seen in the cytoplasm of the macrophages. Multiplying virus particles in crystalline arrays arranged either in single or in multiple clusters were seen in the cytoplasm of macrophages, lymphocytes and light stained reticular epithelial cells.
\end{abstract}

gumboro disease; viral inclusions; viral multiplication.

\section{Introduction}

Infectious bursal disease (IBD), caused by a bisegmented RNA virus, is a highly contagious malady of 2-9 week old chickens. It is characterized by lymphocytolysis and reticular cell proliferation in the lymphoid organs chiefly the bursa of Fabricius (BF) (Okoye 1984).

The IBD virus has been reported to replicate chiefly in macrophages and less so in reticular cells, heterophils and reticular epithelial cells. There is still controversy over the replication of IBD virus in lymphocytes (Chevile 1967, Lunger \& Maddux 1972, Mandelli \& Valeri 1972, Käufer \& Weiss 1976).

The present study is aimed to describe the ultrastructural alterations induced in the $\mathrm{BF}$ following intrabursal administration of a field strain of IBD virus.

\section{Material and methods}

Eight WLH chicks free from IBD maternal antibody were inoculated intrabursally with $0.2 \mathrm{ml}$ of $10 \%$ suspension (in PBS pH 7.2) of the $\mathrm{BF}$ from chicks collected at $48 \mathrm{~h}$ of infection with the field isolate of IBD virus (Verma et al. 1981). Two chicks were sacrificed each at $6,8,12$ and $24 \mathrm{~h}$ post infection (HPI). Eight chicks were inoculated with 0.2 $\mathrm{ml}$ of PBS to serve as uninfected controls and sacrificed similar to infected chicks.

For electron microscopy $1 \mathrm{~mm}^{3}$ pieces of BF were processed for preparation of blocks embedded in araldite by following the method of Käufer \& Weiss (1976) except that cacodylate buffer was used without sucrose and the dehydration of the tissues was done in ascending grades of alcohol. 
Semithin sections were stained with toluidine blue for light microscopy and the ultrathin sections were stained with uranyl acetate and lead citrate for examination under a Philips EM 420. Virus particles were measured with the help of a monogram as suggested by Ghadially et al. (1981).

\section{Results and discussion}

\section{Light microscopic observations}

Edema, degeneration, necrosis and depletion of lymphoid cells were recorded in the bursal follicles from 8 HPI (Fig. 1). Some of the degenerating mononuclear cells revealed intracytoplasmic inclusions (Fig. 2).

\section{Electron microscopic observations}

At 8 HPI the bursal cells with loose intercellular processes were found widely separated on account of the accumulation of edematous fluid in between them. The edema further progressed with the advancement of infection and by 24 HPI the bursal cells had completely lost these processes and appeared as if floating in a pool of fluid (Fig. 2, 3). There was swelling and dilation of the endoplasmic reticulum (Fig. 4). Some of the affected bursal cells contained intracytoplasmic rounded, electronlucent structures similar to fat vacuoles, which at times were surrounded by a clear halo (Fig. 7). The macrophages in the infected $\mathrm{BF}$ revealed increased number of lysosomes as compared to the controls (Fig. 3).

At times, some of the macrophages were found to be converted into a sac of phagolysosomes containing irregularly scattered virions mixed with other phagocytosed materials including myelin figures. There was condensation and margination of the chromatin materiel in the nucleus of the affected cells. The observed morphological changes are in accordance with those described by Käufer \& Weiss (1976).
The intracytoplasmic inclusions in the macrophages were fully packed with virions enclosed by a membranous structure (Fig. 6). There are only few reports on the occurrence of such intracytoplasmic inclusions in the BF of IBD infected birds (Lunger \& Maddux 1972, Mandelli \& Valeri 1972, Hofstad et al. 1984).

The virus particles multiplying either in single or in multiple clusters without any enclosing membrane were seen in lymphoid cells, macrophages and light stained reticular epithelial cells (Fig. 5, 7). The virions measured 40-50 $\mathrm{nm}$ in diameter and contained an electron-lucent to electron-dense core. They were spheroid to hexagonal in shape and arranged in crystalloid pattern. The morphological features and the location of the particles in the infected cells, in general, resembled with the observations of Mandelli \& Valeri (1972) and Almeida \& Morris (1973). The kind of cells supporting IBD virus replication in BF in the present study are in accordance with those reported by Mandelli \& Valeri (1972) and Käufer \& Weiss (1976).

The present study, however, did not reveal replication of IBD virus in heterophils as reported earlier by Käufer \& Weiss (1976). A few of the infected bursal cells had nuclear blebs which have not been reported earlier in IBD infection.

\section{Acknowledgements}

The authors are thankful to Prof. H. J. Hansen, the Director of SIDA Programmes in Veterinary Pathology, Swedish University of Agricultural Sciences, Uppsala, Sweden, and the Director of I.V.R.I., Izatnagar, India for extending all the possible help for completing the study.

\section{References}

Almeida J D, Morris R: Antigenically-related viruses associated with infectious bursal disease. J. Virol. 1973, 20, 369-375. 
Chevile NF: Studies on the pathogenesis of Gumboro disease in bursa of Fabricius, spleen and thymus of chicken. Amer. J. Path. 1967, 51, 527551.

Ghadially FN, Jackson P, Junor J: A monogram for electron microscopists. J. Submicros. Cytol. 1981, 13, 95-96.

Hofstad M S, Barnes J J, Calnek B W, Reid WM, Yoder $H W$ : Diseases of Poultry. 8th ed., Iowa State University Press 1984.

Käufer I, Weiss E: Electron microscopic studies on the pathogenesis of infectious bursal disease after intrabursal application of a causal virus. Avian Dis. 1976, 20, 283-495.

Lunger $P$ D, Maddux T C: Avian infectious bursal agent. I. In vivo viral morphogenesis. Avian Dis. 1972, 16, 874-893.

Mandelli $G$, Valeri A: Reperti ultramicroscopici della Borsa di Fabrizio nella malattia di Gumboro. (Ultramicroscopic findings of the bursa of Fabricius in Gumboro disease). Folia Vet. Lat. 1972, 2, 785-820.
Okoye J O A: Infectious bursal disease of chickens. Vet. Bull. 1984, 54, 425-436.

Verma K C, Panisup A S, Mohanty G C, Reddy B C: Infectious bursal disease (Gumboro disease) and associated conditions in poultry flocks of Andhra Pradesh. Ind. J. Poult. Sci. 1981, 16, 385-392.

\begin{abstract}
Sammanfattning
Electronmikroskopi av Bursa Fabricius hos kyckling efter infektion med en vild stam av IBD virus.

Infekterad kycklingbursa visade inter- och intracellulärt ödem, förtätning och marginering av kärnkromatin, ökat antal lysosomer i makrofager och lymfocytolytiska förändringar från 8 tim. efter infektion. Inklusionskroppar med sfäriska till sexkantiga viruspartiklar sågs i makrofagernas cytoplasma. Viruspartiklar under förökning i kristalliniska strảk ságs i enstaka eller multipla grupper i cytoplasman av makrofager, lymfocyter och epiteliala retikelceller.
\end{abstract}

(Received September 21, 1987).

Reprints may be requested from: Bertil Järplid, Swedish University of Agricultural Sciences, P. O. Box 7028, S-750 07 Uppsala, Sweden. 

A. S. Panisup, B. Järplid, K. C. Verma and G. C. Mohanty: Electron microscopy of bursa of Fabricius of chicks infected with a field strain of infectious bursal disease virus.
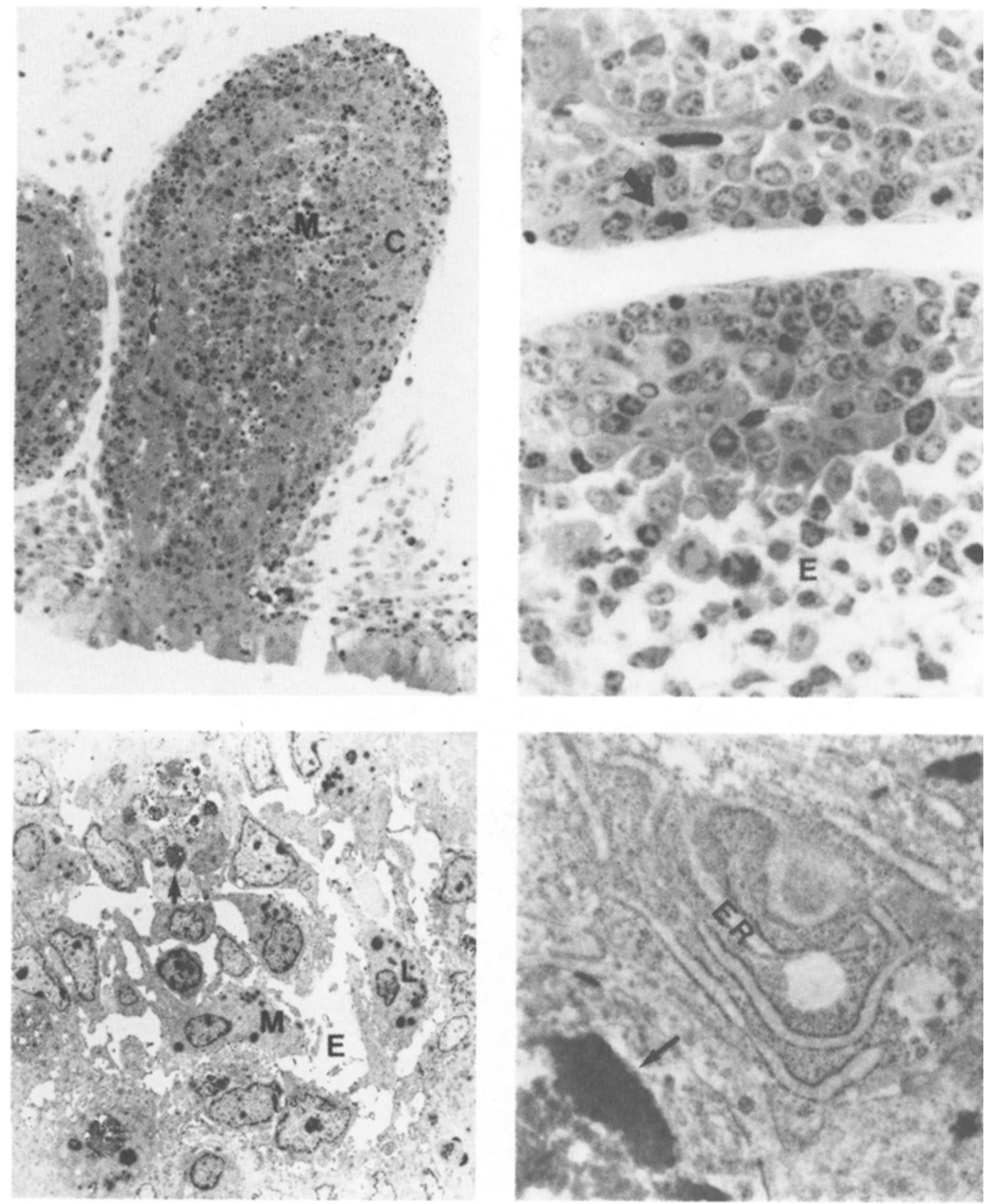

Figure 1. Plica of IBD virus infected bursa of Fabricius with degeneration and depletion of lymphoid cells in cortex $(C)$ and medulla $(M)$. Toluidine blue $\times 280$.

Figure 2. Bursal follicles with edema (E) and IBD viral inclusion (arrow) in mononuclear cell. Toluidine blue $\times 1120$.

Figur e 3. Bursa of Fabricius showing intercellular edema (E), lysosomes (L) in macrophages $(M)$ and intracytoplasmic viral inclusion (arrow). $\times 3000$.

Figure 4. Dilated endoplasmic reticulum (ER) and condensation of chromatin material (C) in IBD affected bursal cells. $\times 33000$. 

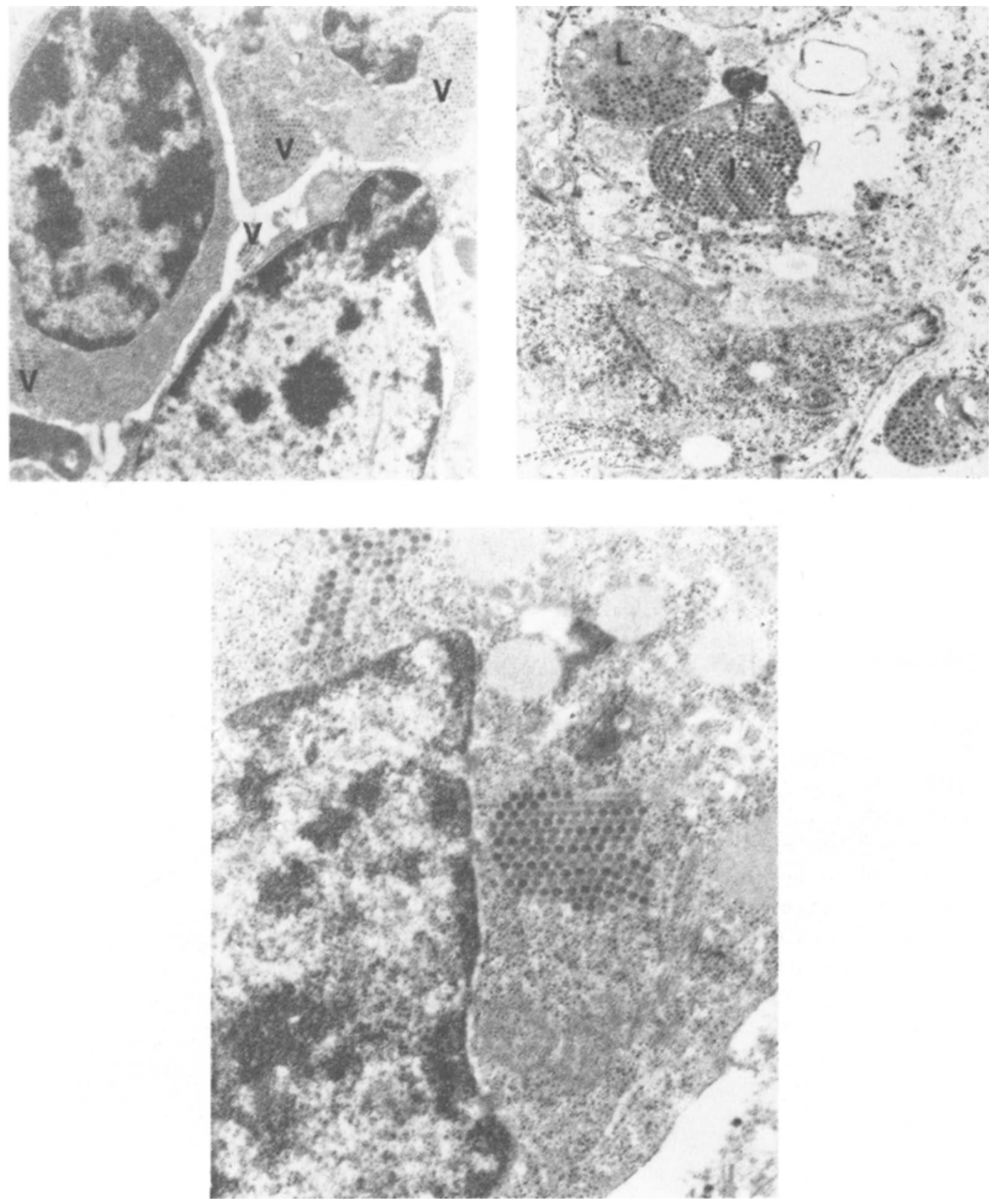

Figure 5. Inter- and intracellular IBD virus particles $(V)$ in bursal cells. $\times 16800$.

Figure 6. Macrophage showing virus particles in phagolysosome (L) and in inclusion (I) in crystalline form. $\times 16800$.

Figure 7. Bursal cell with IBD virus particles and fat vacuoles in the cytoplasm. $\times 41100$. 